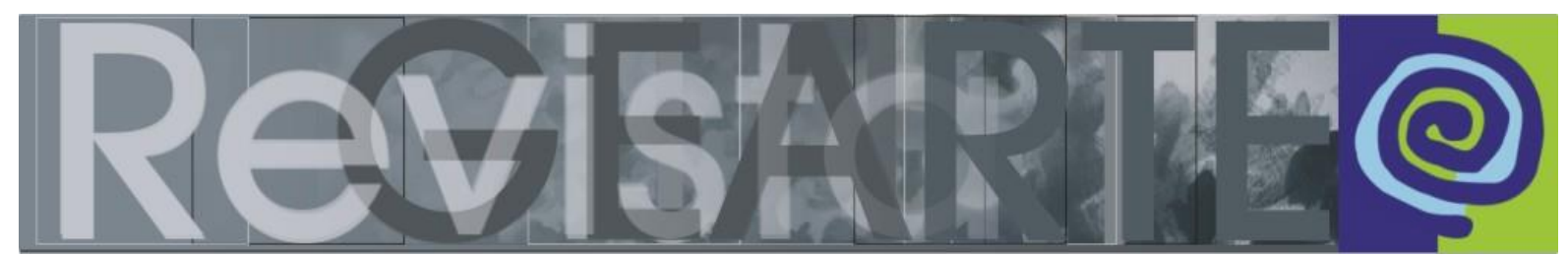

ISSN 2357-9854 | e-ISSN 2596-3198 (online)

\title{
O marajoara que há em nós \\ ou \\ Do desenho que nos une
}

Roberto Carvalho de Magalhães

(Oxford, Connecticut, Estados Unidos)

\section{Introdução}

Sou um desenhista compulsivo. Desenho todos os dias e se, porventura, passo um dia sem desenhar, provo um irremediável sentimento de culpa por não ter desenhado. $\mathrm{O}$ desenho me acompanha, até onde consigo lembrar, desde os quatro anos de idade, quando, sentado na escada de madeira envernizada de casa, lembro ter desenhado algo que deveria ser presumivelmente uma cabra. Os anos foram se passando e, ao contrário do que acontece com a maioria das crianças, não parei de desenhar com a alfabetização. Tudo era, para mim, um pretexto para fazer um desenho, sem contar os desenhos espontâneos, que não precisavam de pretexto algum: a geografia me estimulava a desenhar mapas e bandeiras de países e estados; meus cadernos de biologia pululavam de mitocôndrias, anatomia humana e tipologias de folhas - lanceoladas, lobadas, cordiformes...; os de geometria enchiam-se dos mais complicados poliedros; e nem mesmo os cadernos de Português escapavam à rabisqueira e apresentavam aqui e ali retratos de escritores ou "ilustrações" de contos e romances. Aos catorze anos, por causa da minha habilidade com o desenho, fui convidado a trabalhar em um escritório de arquitetura na mesma rua de casa. A timidez me fez recusar a oferta. Me parecia também que, se aceitasse, ficaria prisioneiro de uma escolha prematura. Bobagem (ou medo) de adolescente.

Acabei optando pelo curso de Letras - Português, Grego, Francês - e pelas veredas da literatura, que logo se tornaram "teoria literária" e que eu percorria com o mesmo grande entusiasmo com que estudava música. E o desenho? Nunca parei. Fiz ilustrações para os contos de Dalton Trevisan, tirinhas - me lembro dos 


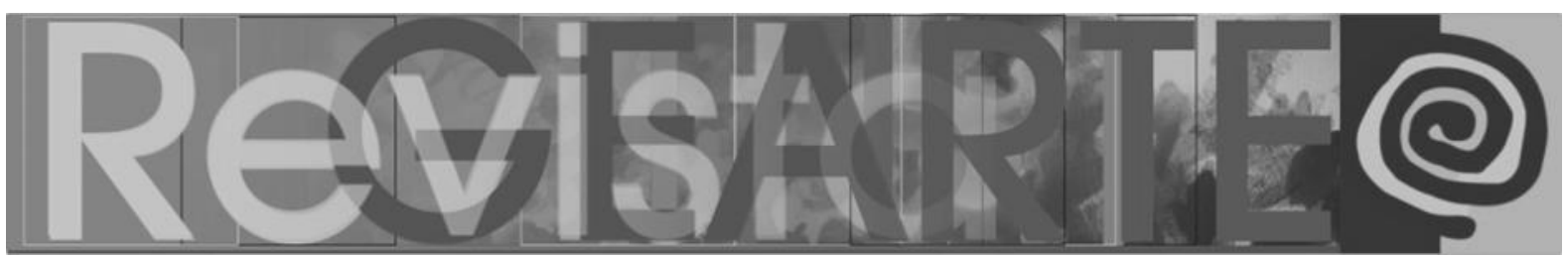

quadrinhos com a desastrada história italiana de "Matilde e la ricottina" -, goaches sem tema definido. Nada para ser mostrado. Desenhava para mim, quase como a proteger o desenho de todo e qualquer tipo de utilitarismo e/ou expectativas externas. Era um exercício de liberdade.

Pouco mais tarde, a decisão de estudar história da arte, crítica de arte e ciência dos museus - e, como consequência dos meus estudos e pesquisas na Itália, acabei me tornando docente universitário nessas disciplinas - foi, no fundo, uma tentativa e/ou necessidade de conciliar o desenho, a expressão visual, com tudo o que eu vinha fazendo até então. Ainda que a atração pela história, pela crítica e pela teoria da arte fossem muito grandes, elas não conseguiram satisfazer ou suplantar o desejo do desenho. Os meus blocos de anotações dos anos de estudo se encheram de desenhos, exercícios livres - abstratos e figurativos -, "cópias" de quadros, estudos de luz e sombra, de volumes, pequenas paisagens, motivos ornamentais gregos, egípcios, africanos, análises geométricas de quadros e esculturas, árvores...

As árvores talvez tenham sido o primeiro sinal de que o desenho estava prestes a reivindicar mais espaço e tempo nas minhas ocupações. Aconteceu na Provença, França, onde estive pela primeira vez em 1991 e, em seguida, todos os anos, nos meses do verão, até 1998. As árvores sempre me encantaram e uma delas é coprotagonista do conto de abertura - "Hit-parade" - de um livro meu nunca publicado. Sob a luz intensa e o céu profundamente azul da Provença, esse encanto se intensificou repentinamente. Nunca tinha prestado tanta atenção nas árvores como, agora, nos pinheiros provençais. E tive que desenhá-los. Me pareciam desenhos esperando a hora de ir para o papel. Também tive que desenhar os contrastes intensos de cores oferecidos pelo céu, pela água e pelos rochedos da porção costeira da Provença em que me encontrava. E, também, não pude evitar pensar em quão motivador, inspirador ou como quer que o chamemos, tudo isso deve ter sido para dois pintores tão antitéticos quanto Cézanne e Van Gogh. 


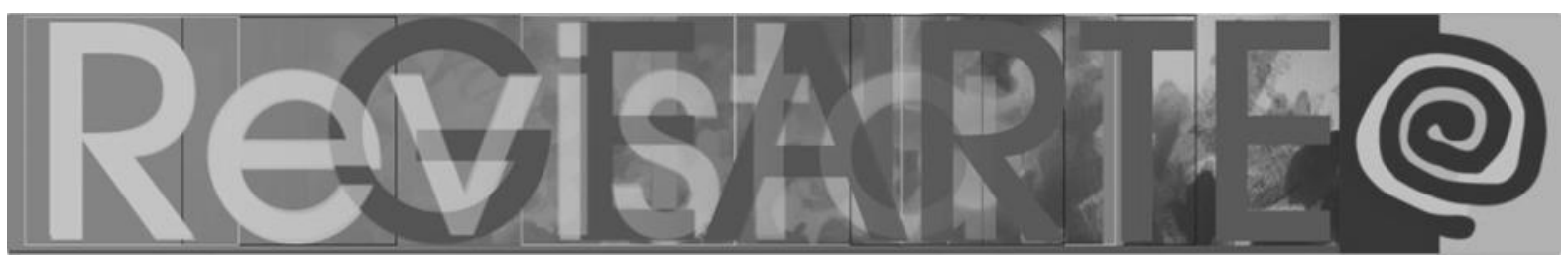

O pastel seco, o carvão - seco ou oleoso - e a sanguínea passaram a reivindicar a mesma atenção dada à caneta (nunca deixei de escrever à mão, o que, para mim, não deixa de ser um tipo de desenho) e o teclado. Passei a desenhar quase na mesma medida com que escrevia meus artigos e ensaios, ainda que sem outro objetivo se não o de exercer privadamente a liberdade de me expressar por imagens. As pastas com desenho foram se enchendo. Ao mesmo tempo, a história da arte e os estudos literários iam se cruzando. Em 1997, a revista Literatura e Sociedade, da Faculdade de Filosofia, Letras e Ciências Humanas da USP, publicava o meu ensaio "A pintura na literatura"1, uma introdução a esse fenômeno interdisciplinar e resultado de leituras e anotações apaixonadas dos anos anteriores. Mais um sinal de que o desenho, ainda que de forma velada, reivindicava o seu espaço num mundo dominado por palavras.

As árvores que "pediam para ser desenhadas" foram se multiplicando. A elas, foram se juntando arquiteturas, retratos, autorretratos... Em 2011, eu deixava o ensino em Florença e, de certa forma, a vida acadêmica; e, em 2013, me mudaria para os Estados Unidos, na zona rural de Connecticut, circundado por árvores, que, especialmente no inverno, são desenhos vivos à espera de serem tranferidos para o papel. Desde então, esse tem sido o período de maior liberdade intelectual e expressiva que eu vivi até aqui. Não é uma coincidência que o desenho tenha assumido o primeiro plano. Ele foi, desde aqueles quatro anos de idade sentados com papel e lápis na mão, na escada de madeira envernizada de um sobrado ao lado do Museu Paulista, o espaço da liberdade, da experimentação, do devaneio, cujo único compromisso era e ainda é o de ser si próprio, num mundo competitivo e verborrágico.

Não, não renego nada do passado. Carrego todas essas etapas como um tesouro que, com os fatos imponderáveis que interferem na vida de cada um de nós, me trouxeram para onde estou. E, também, não renunciei à escrita - manual e digital. Mas tudo isso se modificou, se "redesenhou" e assumiu novas formas, que justificam, dão pleno sentido às pesquisas, aos ensaios e artigos do passado. Os meus escritos assumiram a liberdade do diário - cujo primeiro caderno já 


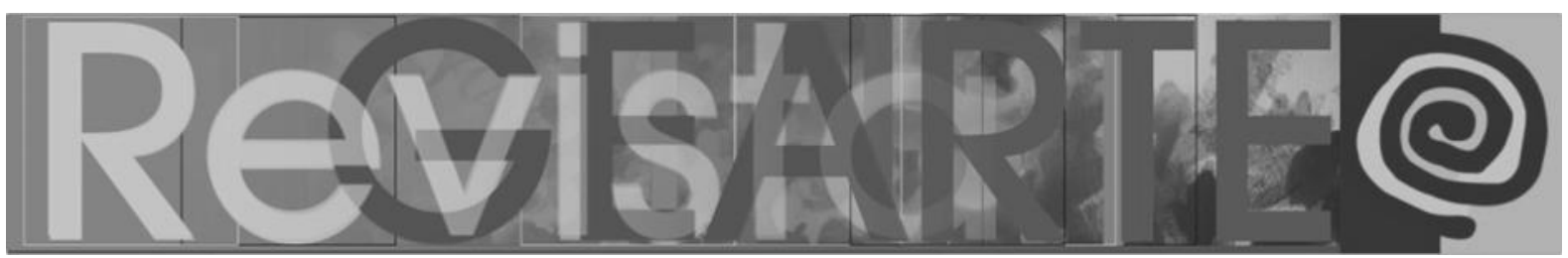

remontava a 1999. Em 2014, quando fui convidado a participar de um seminário organizado pela Profa. Ana Angélica Albano, então diretora do Museu de Artes Visuais da Unicamp, "O que a arte ensina a quem ensina arte", a minha fala foram páginas extraídas do meu diário. Inesperadamente, me tornei também um autor e ilustrador de livros infanto-juvenis. Em 2015, as árvores que pedem para ser desenhadas tornaram-se tema de um conto ilustrado, publicado em 2017: $A$ árvore ${ }^{2}$. A particularidade na concepção desse conto é que não foi ilustrado a posteriori. Ao contrário: primeiro nasceram as imagens, que, em seguida, forneceram as ideias para a história. Foi o desenho que abriu o caminho.

Hoje em dia, rabisco algumas horas por dia. Às vezes, vários desenhos; às vezes, um só. Outras histórias nasceram de desenhos e há desenhos que são eles próprios a história, uma história sem palavras, que se exaure no seu próprio processo criativo.

\section{A história de um desenho que pede para ser contada e as suas implicações conceituais}

Normalmente, nos meus desenhos, prefiro evitar as alegorias visuais - ou as imagens com caráter simbólico. Porém, um dia, decidi desenhar um fragmento de pé, como se pertencesse a uma escultura antiga, sobre o qual e ao redor do qual caminhavam formigas. O desenho se transformou em óbvia alegoria da transitoriedade das coisas, um "memento mori”. Então, resolvi explorar um pouco esse filão. Nasceram um fragmento de rosto, sempre de uma escultura grega, com ramos de hera e grama crescendo-lhe em volta, e uma ânfora grega com motivos geométricos boiando na água, com um nadador passando a certa distância, sem a notar. 


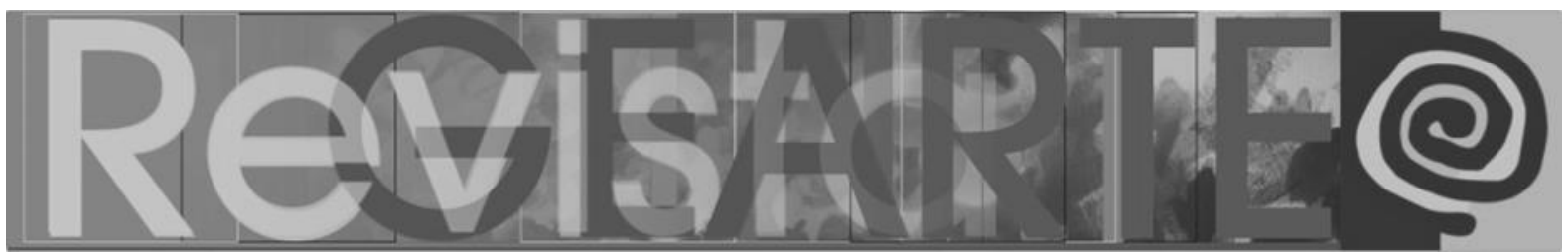

Figura 1 - Sem título, desenho sobre papel, carvão seco e caneta, Caneta Pilot G2 07

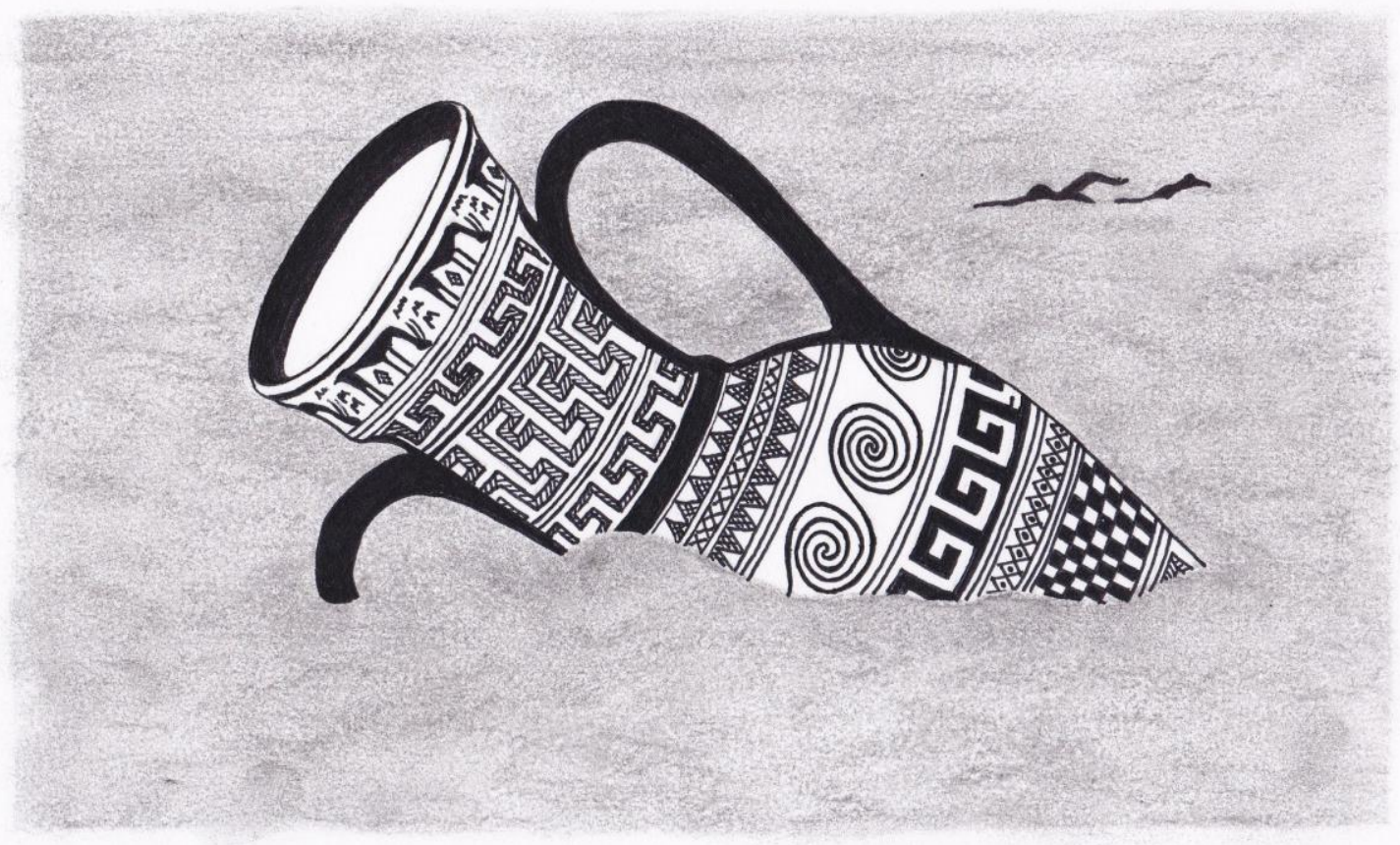

Fonte: Acervo de Roberto Carvalho de Magalhães, 2020.

A essa altura, me veio a pergunta: por que me limitar à escultura e à cerâmica grega antiga? E as civilizações pré-colombianas e africanas? Decidi que o desenho seguinte seria o de uma urna funerária amazônica, provavelmente marajoara, cuja fotografia tinha me encantado. Eu a colocaria deitada no chão sendo consumida por chamas, uma alusão aos incêndios criminosos que estão consumindo a Amazônia, o Pantanal e o Cerrado. O vaso, com alguns traços antropomórficos na parte superior logo abaixo da boca, tem um motivo decorativo linear fascinante ao redor de todo o seu bojo. Trata-se de três linhas paralelas serpenteantes, que formam, repetidamente, redemoinhos alinhados em sentido horizontal, em grupos de três. O contraste entre a beleza da urna, reproduzida em branco e preto, e o fogo que a destrói acrescentaria dramaticidade à imagem. 


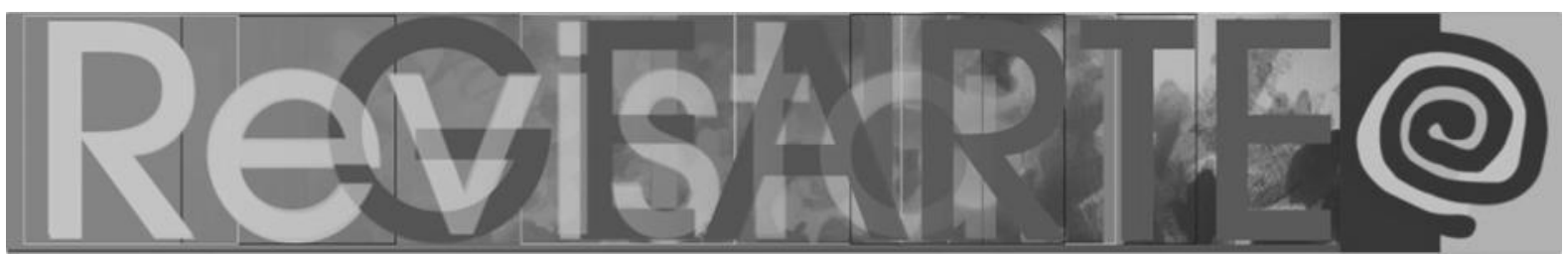

Figura 2 - Cópia de urna funerária marajoara pré-colombiana (400 d.C. a 1.400 d.C.). Caneta Pilot G2 07 sobre papel

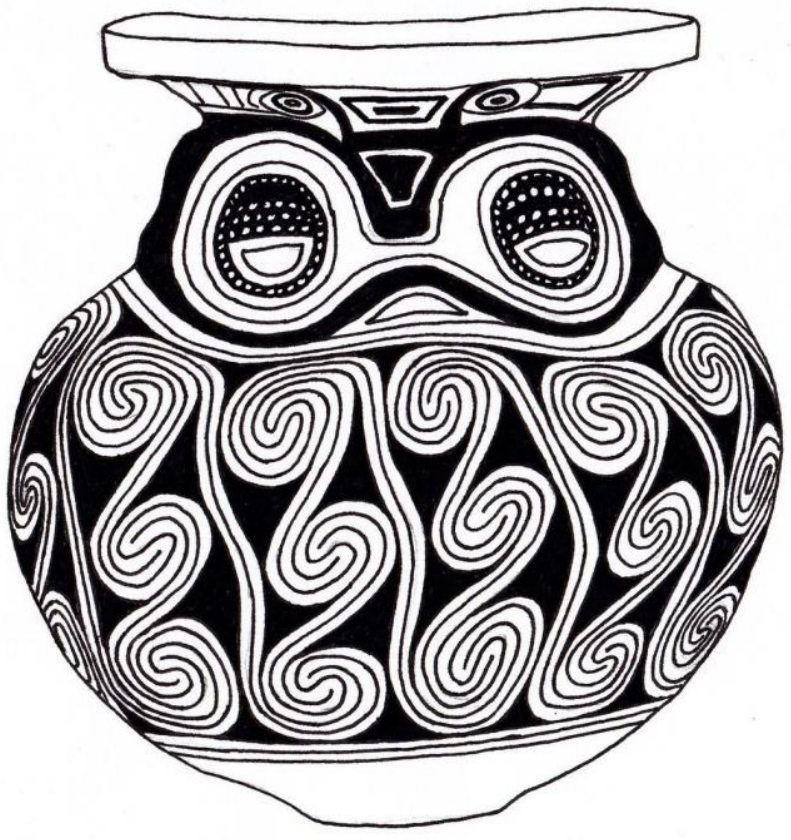

Fonte: Acervo de Roberto Carvalho de Magalhães, 2020.

Mas o verdadeiro drama - o drama criativo - aconteceria nas horas e nos dois dias seguintes: a descoberta de que reproduzir com exatidão o motivo decorativo da urna em um desenho a mão livre não seria uma tarefa nada fácil. $A$ reprodução do motivo labiríntico sistematicamente repetitivo e rítmico envolveu horas de trabalho e observação. Trabalho durante o qual eu pensava: "e estou só copiando um modelo. Quanto trabalho e quanta ciência exigiu o original?". A trabalheira com o desenho dessa peça marajoara pré-colombiana me lembrava também o refinamento e a dificuldade técnica de outra peça: o bracelete de Mezin. Trata-se de uma peça em marfim de cerca de 17.000 a.C., achado no sítio arquelógico de Mezin, na atual Ucrânia.

O bracelete é inteiramente gravado com um motivo geométrico de meandros entrelaçados. Esse motivo foi executado sobre a superfície cônica do marfim, certamente antes que a camada superficial da presa de mamute que constitui o bracelete fosse separada do seu miolo. Portanto, o autor (ou reprodutor) do motivo MAGALHÃES, Roberto Carvalho de. O marajoara que há em nós ou Do desenho que nos une. 175 Revista GEARTE, Porto Alegre, v. 8, n. 1, p. 170-180, jan./abr. 2021. 


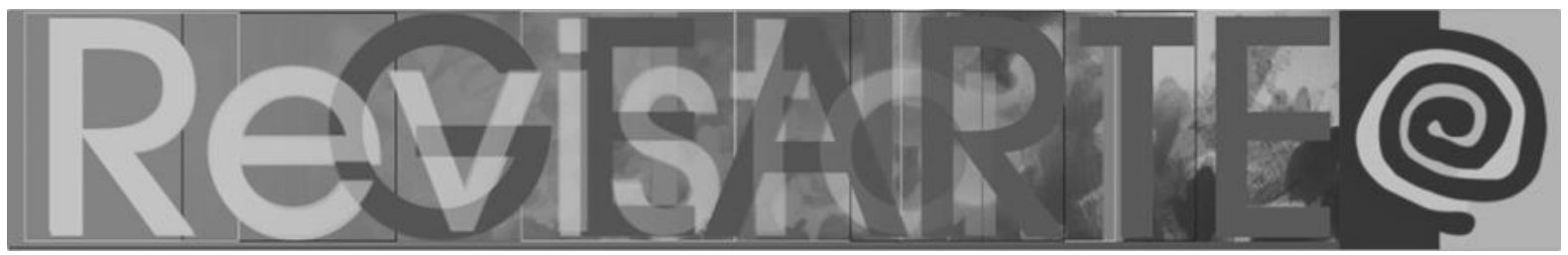

não possuía nem mesmo a visão de conjunto do que estava fazendo, o que implicava um domínio quase absoluto das formas concatenadas que estava criando. Ora, mesmo a partir de uma reprodução plana desse conjunto de meandros concatenados, é muito difícil reproduzi-lo sobre o papel com um lápis. Temos o lápis e o papel, que nos chegam já feitos; temos a borracha, que nos ajuda a apagar todos os erros; temos a imagem reproduzida, plana - portanto, com a visão de conjunto que o autor do original não tinha; e, mesmo assim, reproduzilo à mão é um verdadeiro desafio.

Figura 3 - Transposição para o plano do bracelete de Mezin (Ucrânia) de 17.000 a.C.

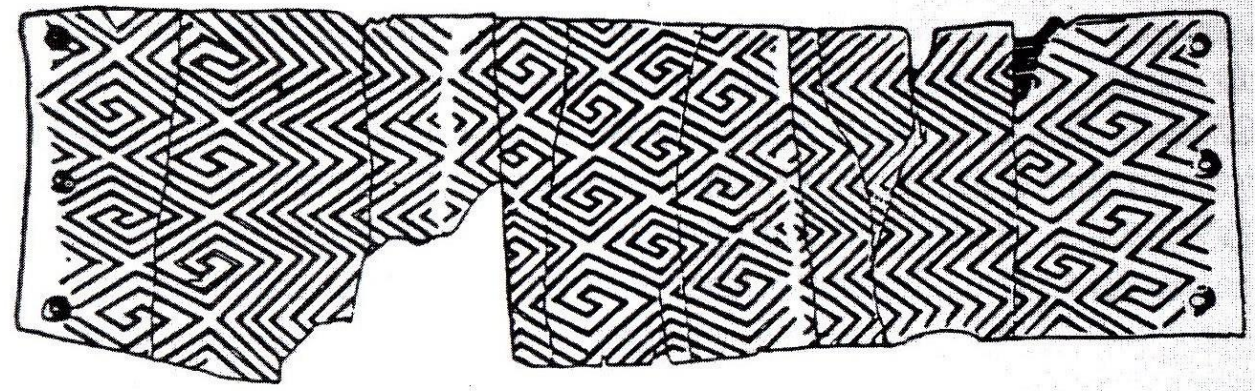

Fonte: Reprodução extraída do livro L'uomo cosciente. Arte e conoscenza nella paleostoria, de Carlo Ludovico Ragghianti. O bracelete de marfim de mamute se encontra no Museu Nacional de História da Ucrânia, em Kiev.

Essas considerações me levam aos anos 80, quando frequentava os encontros com Carlo Ludovico Ragghianti, em Florença, o qual também foi meu orientador. Em 1981, três anos antes de eu chegar à Itália, Ragghianti havia publicado o livro L'uomo cosciente. Arte e conoscenza nella paleostoria ${ }^{3}$. Nele, o filósofo, historiador e crítico de arte sustentava que, se analisássemos os artefatos da assim chamada pré-história no que eles nos mostram objetivamente - ou seja, na sua forma, nos seus elementos técnicos -, ao invés de nos perdermos em hipóteses de uso e função que não podemos demonstrar, eles nos revelariam uma capacidade mental e de equacionar problemas do homem "primitivo" (coloquemos muitas, muitas e muitas aspas) equiparável à do homem moderno. Essa capacidade é atingida antes da elaboração da escrita e, quiçá, é ela que torna a escrita possível. A constatação leva o estudioso a substituir o termo "pré-histórico" por "paleo-histórico", ou seja, no início da história - e não anterior a ela. 


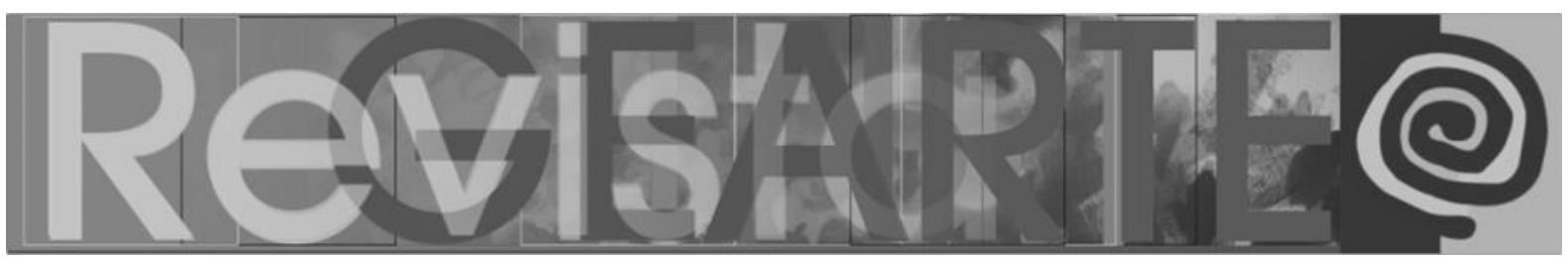

No livro, entre os objetos analisados, encontra-se o bracelete de Mezin. Nas suas aulas, Ragghianti nos exortava a reproduzir à mão o motivo de meandros concatenados. Quem quer que tentasse se dava conta da dificuldade e do refinamento técnico e mental que a elaboração da peça tinha exigido. Essa constatação não vinha sem implicações antropológicas e históricas importantes. Primeiro, indicava que esse homem "primitivo", "balbuciente", não era tão primitivo assim. Segundo, que o desenho e a arte são pensamento, elaboração cognitiva sem palavras, independente delas. Terceiro, que era preciso rever a nossa concepção de "primitivo" não só aplicada à "pré-história", mas também a toda e qualquer cultura que antecede a chegada dos europeus seja na África, nas Américas, na Ásia ou na Oceânia - e, enfim, promover a reabilitação dessas culturas. Acho que esse foi um dos melhores ensinamentos que tive.

Agora, a experiência do bracelete de Mezin, as sensações a ela ligadas e a emoção da descoberta se reacendem com o desenho da urna funerária marajoara. Uma das analogias que encontramos entre os dois objetos é que o vaso bojudo de cerâmica, assim como a forma cônica da presa de marfim do qual o bracelete foi extraído, não permitia ao artista que o decorou a visão de conjunto do seu trabalho. Ele precisava ter perfeito domínio do desenho, das suas concatenações, para poder executá-lo sem hesitação. Um domínio espantoso. Teria sido ele o criador do motivo ou, simplesmente, através da prática, o transmissor de algo criado antes dele e que havia sido transmitido de geração a geração? Não sabemos. Mas sabemos que, em algum momento, um homem - ou uma mulher - o desenvolveu e o fixou com extrema sapiência e elegância no globo de barro. 


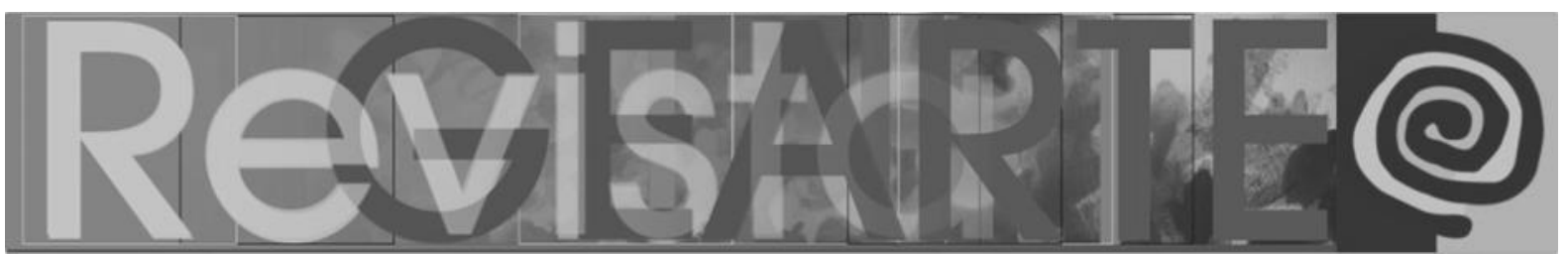

Figura 4 - Sem título. Colagem com desenho a grafite e caneta Pilot G2 07 recortado

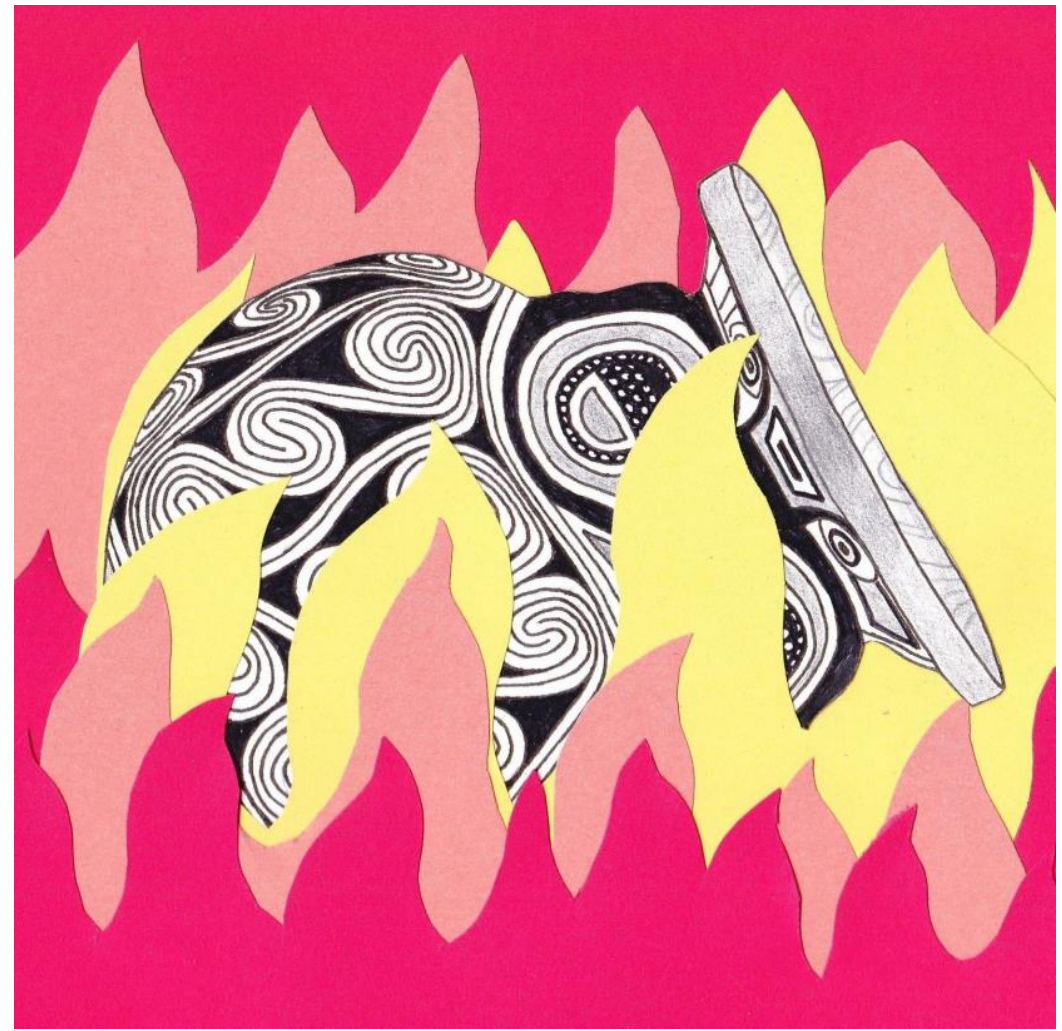

Fonte: Acervo de Roberto Carvalho de Magalhães, 2020.

Quando comparo esse motivo visual com os motivos decorativos da ânfora grega do século VIII a.C. que eu tinha desenhado anteriormente, constato que ele é de execução muito mais difícil. Os refinados motivos geométricos da ânfora grega - que, com grande diligência e prazer, eu tinha copiado/adaptado no meu desenho anterior ao da urna funerária marajoara - são muito mais simples. Na parte alta do seu bojo, eu tinha substituído a faixa com a repetição de um motivo "orgânico" por uma interpretação linear do motivo ininterrupto de ondas, comum na Grécia antiga, seja na arquitetura, seja na decoração de cerâmicas. Nenhum desses motivos contínuos que preenchem as várias faixas horizontais em que a ânfora é dividida oferece o desafio técnico que o bracelete de Mezin e a urna funerária marajoara propõem.

A datação da cerâmica marajoara reproduzida no meu desenho vai de 400 d.C. a 1.400 d.C., a mesma de um lindo vaso globular que se encontra no Museu Nacional do Rio de Janeiro. Portanto, ela remonta a antes da chegada dos 


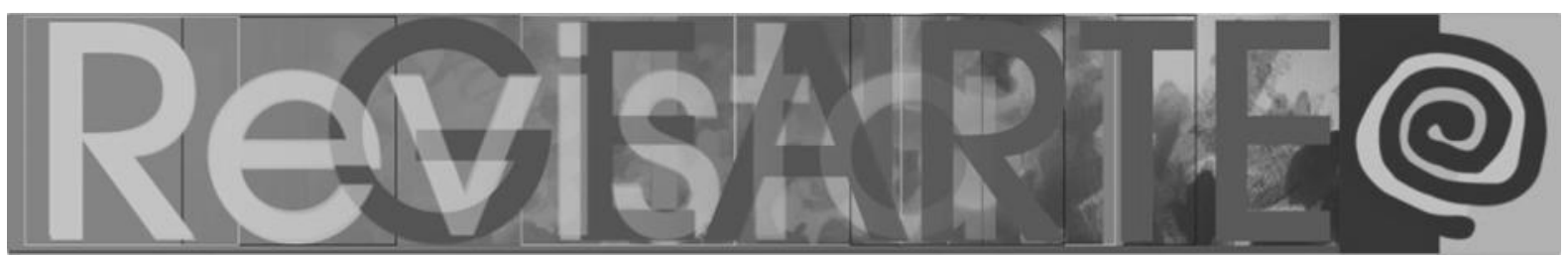

portugueses no continente. O vaso globular do Museu Nacional tem um motivo linear espiralado e ondeante semelhante ao da urna, ainda que menos complexo. O motivo é associado ao movimento das águas e se repete, com variações, em outros objetos. Desconheço o paradeiro da urna funerária. Sei que esteve presente em um catálogo da casa de leilões Sotheby's. Mas nem a sua localização atual, nem o eventual significado simbólico do motivo linear espiralado são relevantes aqui. O que interessa é a complexidade em si do desenho e o indiscutível alto nível técnico da sua execução.

Parafraseando Carlo Ludovico Ragghianti, meu saudoso professor italiano, a pintura dessa urna revela a capacidade de conceber uma trama visual refinada e de grande dificuldade técnica, o que o afasta drasticamente da definição de "primitivo" e o aproxima muito do mundo que consideramos evoluído e sofisticado. Acho fundamental sublinhar isso no mundo de hoje - o mundo "evoluído" e "sofisticado" -, que permite a grilagem das terras dos índios da Amazônia, a destruição das culturas indígenas e do seu rico patrimônio criativo, material e imaterial, como se ainda estivéssemos na época dos "descobrimentos", que não foram nada mais, nada menos do que invasões. Não podemos reverter a história, mas podemos fazer justiça através da retratação histórica. É esse o sentido do meu desenho final, que acabou sendo uma colagem - enfim, o sentido que eu gostaria que ele expressasse: a criminosa destruição de uma imensa riqueza que sequer tivemos a decência de compreender e apreciar. 


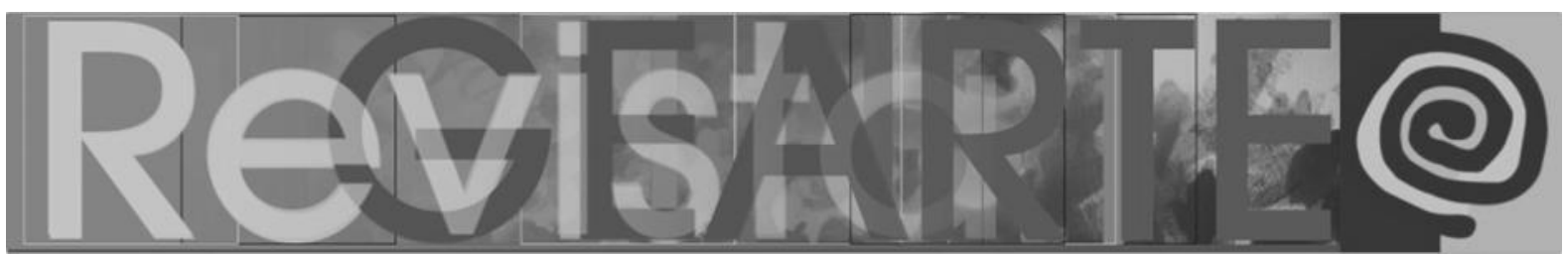

Figura 5 - 0 marajoara que há em nós. Carvão seco e caneta Pilot G2 07 sobre papel

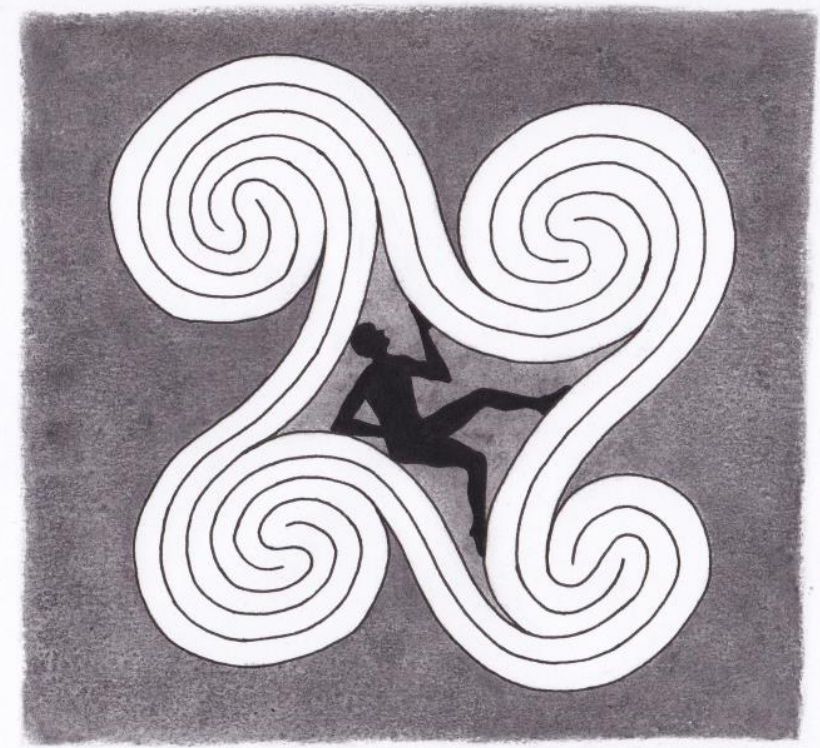

Fonte: Acervo de Roberto Carvalho de Magalhães, 2020.

\section{Notas}

1 MAGALHÃES, Roberto Carvalho de. A pintura na literatura. Literatura e Sociedade, USPFFLCH, São Paulo, v. 2, n. 2, p. 69-88, 1997. Disponível em: https://www.revistas.usp.br/ls/ article/view/13269. Acesso em: 10 out. 2020.

2 MAGALHÃES, Roberto Carvalho de. A árvore. São Paulo, SESI-SP Editora, 2017.

3 RAGGHIANTI, Carlo Ludovico. L'uomo cosciente. Arte e conoscenza nella paleostoria. Bolonha: Calderini, 1981.

\section{Roberto Carvalho de Magalhães}

É historiador, crítico de arte e especialista em museus. Estudou História da Arte, Crítica de Arte e Ciência dos Museus em Florença e teve como orientador o filósofo e crítico d'arte italiano Carlo Ludovico Ragghianti. Por mais de vinte anos, foi docente dessas três disciplinas na Università Internazionale dell'Arte, de Florença, e, no mesmo período, escreveu sistematicamente para a revista Critica d'Arte, para o jornal "La Nazione" e organizou e supervisionou coleções para a editora McRae Books. Ao mesmo tempo, manteve uma profícua colaboração com o Museu de Arte de São Paulo - que culminou, entre outras, na curadoria da exposição de longa duração A Arte do Mito (2007). Em 2013, muda-se para os Estados Unidos, onde escreve seus ensaios sobre arte, contos e realiza suas pesquisas sobre o desenho, além de se dedicar ao trabalho de ilustrador. De 2017, é seu livro infanto-juvenil (texto e ilustrações) $A$ árvore, publicado pelo SESI-SP Editora, com a qual já tinha colaborado, produzindo os textos para uma coleção para a infância de mitos grega, com ilustrações da artista Sônia Magalhães.

ORCID: https://orcid.org/0000-0003-4604-1900

E-mail: gamacor12@hotmail.com

Recebido em 1 de dezembro de 2020 Aceito em 20 de fevereiro de 2021 